\title{
FACTORS AFFECT COMPANY VALUE IN MANUFACTURING COMPANIES LISTED IN INDONESIA STOCK EXCHANGE
}

\author{
LINDA SANTIOSO \\ NURAINUN BANGUN \\ YUNIARWATI
}

Faculty of Economics, Tarumanagara University, Jl. Tanjung Duren Utara No. 1, Jakarta Barat 11470, Indonesia linda.santioso@gmail.com, yuniarwati@fe.untar.ac.id, Inun66@yahoo.com

\begin{abstract}
The purpose of this research is to examine the effect of profitability, enterprise risk management and corporate social responsibility on firm value. The sample of this research limited to manufacturing companies listed on the Indonesia Stock Exchange for the period 2013-2015. This research uses 150 data with 50 companies selected per year. Analysis tool used multiple linear regression. The dependent variable on this research is firm value, and the independent variable returns on equity, enterprise risk management, and corporate social responsibility. The result showed that return on equity and enterprise risk management affect the firm value, while corporate social responsibility has no effect on firm value.
\end{abstract}

Keywords: Profitability, enterprise risk management, corporate social responsibility, firm value

Abstrak: Tujuan penelitian adalah untuk menguji pengaruh profitabilitas, manajemen risiko perusahaan dan tanggung jawab sosial perusahaan terhadap nilai perusahaan. Sampel penelitian ini terbatas pada perusahaan manufaktur yang terdaftar di Bursa Efek Indonesia untuk periode 2013-2015. Penelitian ini menggunakan 150 data dengan 50 perusahaan yang dipilih per tahun. Alat analisis menggunakan regresi linier berganda. Variabel dependen pada penelitian ini adalah nilai perusahaan, dan variabel independen profitabilitas, manajemen risiko perusahaan, dan tanggung jawab sosial perusahaan. Hasil penelitian menunjukkan bahwa profitabilitas dan manajemen risiko perusahaan mempengaruhi nilai perusahaan, sedangkan tanggung jawab sosial perusahaan tidak berpengaruh terhadap nilai perusahaan.

Kata kunci: Profitabilaits, manajemen risiko perusahaan, tanggung jawab sosial perusahaan, nilai perusahaan

\section{INTRODUCTION}

Every company has the main goal, to get maximum profit. In this globalization era, competition between companies is getting tougher, requiring companies to be able to face and anticipate all situations in order to be able to survive and stay ahead in the middle of the situation, especially in the context of achieving the company's main goals (Ardimas and Wardoyo 2014). 
Another goal of the establishment of a company is to maximize the value of the company, which can be reflected by the price of its shares. Every company certainly wants a high corporate value because it also implies that shareholder prosperity is also high. (Ardimas and Wardoyo 2014).

There are many factors that can determine the value of a company, one of which is Return on equity. According to (Languju et al. 2016), Return on equity is intended to measure how much profit is the right of the owners of their own capital. The ROE growth shows that the better the prospect of the company means the potential for increasing profits obtained by the company. With the increase in ROE, there is an increase in net income of the company concerned, so that investors can use the ROE indicator as a material consideration to invest their capital, because this ratio shows that if management performance increases, the company can effectively manage operational funding sources for generate net income so that the company's shares are in great demand by investors (Husaini 2012).

Implementing Enterprise Risk Management (ERM) in a company will be able to help control management activities so that companies can minimize the occurrence of fraud that can harm the company. ERM disclosure is information on risk management carried out by the company and reveals its impact on the company's future (Devi et al., 2016).

Companies can provide financial and nonfinancial information to outside parties about risk profiles through ERM disclosure. ERM disclosure also serves as a signal of the company's commitment to risk management (Devi et al. 2016).

At present the company's responsibility must rest on the triple bottom lines, namely corporate responsibility on social, environmental and financial aspects so that each company is required to disclose information about corporate social responsibility (Fitri and Eliada 2014). Corporate Social Responsibility is a form of corporate responsibility in improving social inequalities and the existence of environmental damage caused by the company's operational activities. The more forms of accountability that the company does with its environment; the more the company's image increases (Retno and Priantinah 2012).

The research conducted by (Languju et al. 2016) concluded that ROE had a significant effect on firm value, but the conclusion was in opposite to the research conducted by (Putri 2015) concluded that ROE did not significantly influence firm value.

The research conducted by (Devi et al., 2016) concluded that ERM has a significant effect on firm value, but this conclusion is contradicted with the research conducted by (Agustina and Baroroh, 2014) which concluded that the implementation of ERM did not significantly influence the value of the company.

Research conducted by (Fitri and Herwiyanti, 2014) concluded that disclosure of CSR has an effect on company value. (Ardimas and Wardoyo 2014) which concluded that CSR practices did not affect the value of the company contradict this conclusion with the result that obtained from the research conducted.

From a number of previous studies that have been described previously which examine the influence of the three variables, namely: Return on Equity, enterprise risk management and corporate social responsibility still produce results that are diverse and inconsistent with the value of the company?

Therefore, in this research we will examine again whether there is a significant influence between Return on Equity, Enterprise Risk Management, and Corporate Social Responsibility on the value of the company in 
manufacturing companies listed on the Indonesia Stock Exchange? Based on the formulation of the problem above, the purpose of this study is to prove empirically the effect of Return on Equity, Enterprise Risk Management and Corporate Social Responsibility on the value of the company.

\section{Stakeholder Theory}

Stakeholder theory mentioned that a company is not an entity that only operates for its own sake but it must provide benefits to its stakeholders. Thus, the existence of a company is strongly influenced by the support provided by stakeholders to the company. Stakeholders are all parties, internal and external, which can influence or be influenced by the company both directly and indirectly (Handriyani and Andayani 2013).

Stakeholder theory is based on assumptions: (1) the company has a relationship with many constituent groups of stakeholders that influence and are influenced by company decisions, (2) this theory emphasizes the nature of relationships in the process and output for the company and its stakeholders, (3) The importance of all stakeholder legitimacy has intrinsic value, and does not form interests dominated by one another, (4) This theory focuses on managerial decision making. Based on the assumption of stakeholder theory, the company cannot escape from the social environment. Companies need to maintain the legitimacy of stakeholders as well as occupy them in the framework of policy and decision-making, hence they can support the achievement of corporate goals, namely business stability and will concern on guarantees (Handriyani and Andayani, 2013).

\section{Signalling Theory}

Signal theory explained why companies present information for the benefit of the capital market (Wulandari et al. 2016). Signal theory indicated that managers give signals to those who have interests in the company to reduce information asymmetry. Companies can use CSR disclosure to reduce information asymmetry, as a signal to provide information to stakeholders that the company has good information. Thus, the signal can attract investors and can build a company image (Wulandari et al. 2016).

Signal theory also suggested about how a company can signal to users of financial statements. This signal can be in the form of information or promotion, which stated that the company is better than other companies. This information and promotion provides information about what has been done by management to realize the wishes of company owners (Wulandari et al. 2016).

Corporate environment disclosure is one of CSR activities where the activity has a dominant motive to give a signal about the quality of its management. The quality of financial reporting is a signal for financial market participants and stakeholders or other stakeholders that showed that management is able to control the environmental and social risks of the company (Wulandari et al. 2016).

In addition, CSR disclosure activities are a good signal for investors and stakeholders that the company has been active in CSR activities so that the company's value is in a good position and can make the company's social performance good. As a result companies get a good reputation from the capital market and debt market (Wulandari et al. 2016).

\section{Company Value}

The value of the company in this research is defined as market value because the value of the company can provide maximum shareholder prosperity if the company's stock price increases. The higher the stock price, it will be the higher the prosperity of shareholders. In order to achieve company 
value, investors generally hand over their management to professionals (Handriyani and Andayani 2013).

A company can be stated to have good value when the company's performance is also good. The value of the company can be reflected in the high price of the company's stock, when the value of its shares is high it can be mentioned that the value of the company is also good. Every company that is established wants the price of shares sold to have a high price potential so that this situation will be in demand by investors, moreover with the increased demand for shares, the value of the company will also increase in order for the company's long-term goal to optimize the company's value. The higher the value of the company describes the more prosperous the owner (Handriani and Andayani, 2013).

\section{Return on Equity}

Definition of Return on equity according to (Kieso et al. 2014): "Return on equity measures profitability from the ordinary shareholders' viewpoint. This ratio showed how many companies the owners invest. Return on equity also helps investors judge the worthiness of a share when the overall market is not doing well. "Return on Equity is one of the profitability ratios. Profitability measures are focused on company profits. Of course, large companies are expected to generate more profits than small companies, so to facilitate cross-company comparisons, total profits are expressed on a per-dollar basis. (Brealey et al. 2011). The return on equity ratio is also called the return on equity. This ratio examines the extent to which a company uses its resources to be able to provide return on equity (Languju et al. 2016). Return on Equity (ROE) is a ratio to measure how much profit is the right of the owners of their own capital. According to (Triagustina et al. 2014),
Return on Equity (ROE) is a ratio to measure a company's ability to generate profits based on certain share capital. This ratio is a measure of profitability from the perspective of the shareholders. The stock price indicated the value of the company, the higher the stock price, the higher the shareholder's profit and the value of the company.

(Triagustina et al. 2014) state that high ROE often reflects the company's acceptance of good investment opportunities and cost effective management. The higher the ratio, the better it means that the position of the company owner is getting stronger. Thus the company will be able to pay dividends to shareholders.

\section{Enterprise Risk Management}

Enterprise risk management is a process, affected by an entity's board of directors, management and other personnel, applied in strategy setting and across the enterprise, designed to identify potential events that may affect the entity, and manage risk to be within its risk appetite, to provide reasonable assurance regarding the achievement of entity objectives" (Coso 2007). However, an ERM is designed to be able to identify potential events that play a role in decision making in the company by managing risk to be at a level of risk that can still be controlled by the company to provide confidence in achieving company goals involving the board of directors, management and company members. The ERM process must be implemented in strategy settings in all parts of the company.

Efforts to improve the quality of implementing risk management can be done through integrated risk management; it is the application of Enterprise Risk Management (ERM). ERM allows management to effectively deal with uncertainties related to risks and opportunities, and to increase capacity to build company value (Committee on Sponsoring 
Organizations of the Tread way Commission (COSO 2007).

ERM is a process that involves the board of directors, management and members of the company, which are implemented in strategy settings in all parts of the company. ERM is designed to identify potential events that can affect the company, and manage risks to be at the level of risk that can be controlled by the company, to provide confidence in the achievement of company goals (Sanjaya and Linawati 2015).

ERM controls the risks faced by companies in an integrated and holistic manner. Failure to identify, assess, and manage risk can result in losses to stakeholders and shareholders. So companies must anticipate risk in a creative way (Sanjaya and Linawati, 2015). In addition, ERM can help companies achieve their main goals and create value through the implementation of ERM, which is directly linked to the formulation of corporate strategy (Sanjaya and Linawati 2015).

The company concerned must manage most of the risks faced by the company. This causes risk management to be necessary for every company (Sanjaya and Linawati 2015).

Risk management is defined as the process by which companies identify risks and take action before and after to control the deviation between risk tolerance and the risks faced (Sanjaya and Linawati, 2015).

(Sanjaya and Linawati, 2015) states that Risk management includes two things : (1) Through direct involvement in the preparation of corporate strategy, risk management can add value to the company. (2) Tactics related to the implementation of risk management in a company so that it can be applied effectively and efficiently.

\section{Corporate Social Responsibility}

The World Business Council for Sustainable Development (WBCSD) defined that corporate social responsibility is continuing commitment by business to behave ethically and contributed to economic development while improving the quality of life of the workforce and their families as well as of the local community and society at large (Agoes and Ardana 2009)

The definition showed that business commitment to continuously behave ethically and contribute to economic development and improve the quality of life of employees and their families, local communities, and the general public in general (Agoes and Ardana 2009).

Concern in for the business community to set aside of funds for CSR activities. Thus, consumers and companies in demand by investors increasingly prefer products. CSR can be used as a new marketing tool if the implementation is in accordance with the company's vision and mission and is carried out sustainably, the company image will be better so that consumer loyalty will be higher (Handriyani and Andayani, 2013).

Increasing customer loyalty for a long time, the sales will increase and ultimately the level of profitability of the company will increase. That is why CSR plays a very important role in increasing the value of the company because of increasing sales of the company by doing various social activities in the environment around the company (Handriyani and Andayani 2013).

Paragraph 12 of the Financial Accounting Standard Statement (PSAK) No.1 (revised 2009) clearly presented that the suggestions for disclosing the forms of responsibility for social problems, namely as follows: Entities can also present separate financial statements, environmental reports and value added reports or value added statement, especially for industries where environmental factors play an important role and for industries that consider employees as a group of report users who play an important role. These additional reports are outside the scope of Financial Accounting Standards. 
Assets that every company that implements CSR in its business activities will get 5 (five) main benefits as follows (Kartini 2009): (1) Increase profitability and stronger financial performance, for example through environmental efficiency, (2) Increasing accountability, assessment and investment community, (3) Encouraging employee commitment, because they are cared for and valued, (4) Reducing vulnerability to turmoil with the community, and (5) Enhancing reputation and corporate branding.

Corporate social responsibility includes three dimensions which are often referred to as 3P (Agoes and Ardana 2009), namely: a. Achieve profit (profit) for the company, $b$. empowering people (people), and C. maintaining the preservation of nature (planet). The company must carry out these three concepts in a balanced manner.

Under the 3P concept proposed (Agoes and Ardana 2009), the concept of CSR actually wants to integrate the three functions of the company in a balanced manner, namely:

a. Economic function, this function is a traditional function of the company, namely to obtain profits (profit) for the company (which is actually the company's interests).

b. Social function, the company carries out this function through human empowerment, namely stakeholders (people / stakeholders) both primary stakeholders and secondary stakeholders. In addition, through this function the company plays a role in maintaining fairness in sharing benefits and bearing the burdens arising from company activities.

c. Natural function, the company plays a role in preserving nature (planet / earth). The company is only one element in the life system on this earth. If the earth is destroyed, then all forms of life on this earth (humans, animals, and plants) will be threatened with destruction.
Based on the explanation above, the proposed hypothesis is as follows:

$\mathrm{H}_{1}$ : Return on equity has a positive and significant influence on firm value.

$\mathrm{H}_{2}$ : Enterprise Risk Management has a positive and significant influence on firm value.

$\mathrm{H}_{3}$ : Corporate Social Responsibility has a positive and significant influence on firm value

\section{METHODS}

The population of this research is all manufacturing companies listed on the Indonesia Stock Exchange (IDX) during 20132015. The samples in this research were 50 manufacturing companies. The object of research is return on equity, enterprise risk management, corporate social responsibility and company value.

Data collection techniques used in this research is literature studies and secondary data. Literature studies are conducted by studying scientific journals, literature books, and other sources related to the research being conducted. According to (Riadi 2015) secondary data is second hand information that has been collected by various people (organizations) for specific purposes and is available for various studies. Secondary data in this research were taken from financial statements and annual reports of manufacturing companies listed on the Indonesia Stock Exchange in 2013-2015.

Sample selection is done by purposive sampling method, namely the technique of determining the sample based on certain criteria or characteristics that have been previously known (Hadi 2015). The criteria for conducting this research are: a) manufacturing companies listed on the Indonesia Stock Exchange for three consecutive years in the period 2013-2015, b) companies that issue 
annual reports for three consecutive years in the period 2013-2015, c) manufacturing companies who issued financial statements that were stated in rupiah and ended on December 31 during the period 2013-2015 respectively, d) companies that did not suffer losses during the period 2013-2015, and e) manufacturing companies that implemented social responsibility in the report yearly for three consecutive years in the 2013-2015 period.

This research uses multiple regression analysis because in this research uses one dependent variable and three independent variables.

$Y=\beta 0+\beta 1$ ROE $+\beta 2 E R M+\beta 3$ CSR $+\varepsilon$

Note:

$\mathrm{Y}=$ Company Value

$\mathrm{BO}=$ Constant

$\beta 1, \beta 2, \beta 3=$ Regression Coefficient

$\mathrm{ROE}=$ Return On Equity

ERM $=$ Enterprise Risk Management

CSR $=$ Corporate Social Responsibility

The dependent variable is the value of the company. Company value is measured using the Price to Book Value (PBV) ratio. The formula used is as follows:

$$
\mathrm{PBV}=\frac{\text { market price per share }}{\text { book value per share }}
$$

The first independent variable is Return On Equity. ROE is the ratio between net incomes to total equity. The higher the ROE shows the more efficient the company uses its own capital to generate net profits or profits. ROE is used to measure the rate of return of the company or the effectiveness of the company in generating profits by utilizing the equity (shareholders' equity) owned by the company. The formula used to measure ROE is:

$$
\text { ROE }=\frac{\text { net income }}{\text { total equity }} \times 100 \%
$$

The second independent variable is Enterprise Risk Management. ERM is measured by looking at ERM disclosures listed in a company's annual report with an unweight dichotomous scale. Every disclosure of an item will be given a value of 1 and 0 if the item is not disclosed, and then the score of each item will be summed to obtain the total score of disclosure for each company. ERM index disclosure can be calculated using the following formula:

$$
\text { ERMDI }=\frac{\sum_{i j} \text { Ditem }}{\sum_{i j} \text { ADitem }}
$$

Note:

ERMDI: ERM Disclosure Index

$\Sigma$ ij D Item: ERM Item Score Total Revealed

Eij AD Item: Total ERM Items That Should Be Revealed

The third independent variable is Corporate Social Responsibility. CSR can be calculated from the CSR disclosure index (CSRI). To determine the level of disclosure of social information in the annual report, a dichotomy approach is used, that is, each CSR item in the research instrument is given a value of 1 if disclosed, and a value of 0 if not disclosed. Furthermore, the score of each item is summed to obtain the overall score for each company. The CSRI calculation formula is as follows:

$$
\text { CSRIj }=\frac{\sum X i j}{n j} \times 100 \%
$$

Note:

CSRlj: Corporate CSR Disclosure Index nj: number of items for company j, nj $\leq 91$

Xij: dummy variable: 1 = if item I is disclosed, 0 $=$ if item I is not disclosed.

Thus, $0 \leq \mathrm{CSRlj} \leq 1$.

\section{RESULT}

The following is a table of results of descriptive statistics and hypothesis testing: 
Table 1 Descriptive Statistics

\begin{tabular}{lccccc}
\hline Variable & $\mathbf{N}$ & Minimum & Maximum & Mean & Std. Deviation \\
\hline RETURN ON EQUITY & 150 & .0010 & .3675 & .135953 & .0820247 \\
ENTERPRISE RISK & 150 & .2963 & .7037 & .508024 & .0801254 \\
MANAGEMENT & & & & & \\
$\begin{array}{l}\text { CORPORATE SOCIAL } \\
\text { RESPONSIBILITY }\end{array}$ & 150 & .0659 & .2198 & .130990 & .0345029 \\
COMPANY VALUE & 150 & -2.22 & 2.11 & .3719 & .97586 \\
\hline
\end{tabular}

Source: (Result of Data Processing SPSS 21.0, 2017)

Table 2 Hypotesis Testing

\begin{tabular}{lccc}
\hline Variable & B & T & Sig. \\
\hline (Constant) & -1.631 & -3.870 & .000 \\
RETURN ON EQUITY & 7.082 & 9.221 & .000 \\
ENTERPRISE RISK MANAGEMENT & 1.952 & 2.417 & .017 \\
CORPORATE SOCIAL RESPONSIBILITY & .370 & .202 & .840 \\
\hline
\end{tabular}

Coefficient regression showed that the direction of change of the dependent variable on the independent variable. From the linear regression equation above, it can be explained that if ROE, ERM and CSR are each zero, then the value of the company will be worth $-1,631$. If the ROE variable increases by one unit, the company value will increase by 7.082 assuming other free variables are considered constant. If the ERM variable increases by one unit then the value of the company will increase by 1.952 assuming other independent variables are considered constant. If the CSR variable increases by one unit, the value of the company will increase by 0.370 assuming the other independent variables are considered constant.

The first hypothesis $\left(H_{1}\right)$ proposed in this research is Return on Equity has a positive and significant influence on firm value. Table 2 above showed the significance value of the ROE variable of 0,000 where the value is smaller than the significance level of 0.05 , then the first hypothesis $\left(H_{1}\right)$ is accepted. This means that ROE has a positive and significant influence on company value. Return on Equity (ROE) is to measure how much profit is the right of the owner of his own capital. The higher the ROE is the better the position of the owner of the company will cause a good assessment of investors to the company, which causes an increase in stock prices, and company value. The result of this research is indicated that ROE has a significant effect on the direction of a positive relationship with firm value (PBV). This means that when the company experiences an increase in profits, the company's stock price will go up so that it will increase the value of the company. ROE becomes a benchmark for investors regarding the company's ability to manage resources that are owned effectively or not. The result of this research is supported by the research of (Languju et al. 2016) which stated that ROE has a positive and significant influence on firm value, but is contrary to the research of 
(Hariyanto and Lestari 2015) which stated that ROE does not have a significant effect on firm value.

The second hypothesis $\left(\mathrm{H}_{2}\right)$ proposed in this research is that Enterprise Risk Management has a positive and significant influence on firm value. Table 2 above showed the significance value of the ERM variable is 0.017 , where the value is smaller than the significance level of 0.05 , then the second hypothesis $(\mathrm{H} 2)$ is accepted. This means that ERM has a positive and significant effect on firm value. ERM is a positive signal because through ERM information, investors will be able to assess the company's prospects. Welfare for investors will be achieved if investors invest in companies that can achieve good performance, so they can generate high dividends for investors. Investors have confidence that more ERM implementation in a company will make it easier for the company to achieve maximum performance. This belief prompted investors to trade stocks so that the volume of stock trading would increase. Positive perceptions held by investors on the company will ultimately increase the company's stock price and will have an impact on increasing the value of the company. The result of this research supported the research of (Devi et al. 2016), which stated that ERM has a positive and significant effect on firm value, but it contradicted the research of (Sanjaya and Linawati 2015) which stated that ERM does not significantly influence firm value.

The third hypothesis $\left(\mathrm{H}_{3}\right)$ proposed in this research is Corporate Social Responsibility has a positive and significant influence on firm value. Table 2 above showed the significance value of the earnings quality variable of 0.840 where the value is greater than the significance level of 0.05 , then the third hypothesis $\left(\mathrm{H}_{3}\right)$ is rejected. This means that CSR does not have a significant influence on the value of the company. This showed that investors do not respond to CSR disclosures that have been made by the company. The resulted of this research supported the research of (Ardimas and Wardoyo, 2014) which stated that CSR does not have a significant effect on firm value, but differed from the research of (Handriani and Andayani 2013) which suggested that CSR has a significant effect on firm value.

\section{CONCLUSION}

The conclusion of this research are: (1) Return on equity has a significant and positive effect on firm value; (2) Enterprise risk management has a significant and positive effect on firm value; (3) Corporate Social Responsibility does not have a significant influence on company value.

The limitations in this research are explained as follows: (1) this research was only conducted on manufacturing companies listed on the Indonesia Stock Exchange as research samples, so that the result of the research could not represent the condition of the entire company. (2) This research only uses a threeyear research period, namely in the period 2013-2015. This causes the result of the research to only describe the conditions that occurred in the last three years. (3) This research only used three independent variables, namely return on equity, enterprise risk management and corporate social responsibility that are expected to affect the value of the company. (4) This research only used annual reports to obtain data related to ERM disclosure conducted by companies. Based on the limitations faced in the implementation of this research, the suggestions that can be given are: (1) Researchers can further expand the research sample, not only using a sample of manufacturing companies but can include all companies listed on the Indonesia Stock Exchange such as mining, telecommunications, real estate companies, 
retail and others. (2) The next researcher can add years of research, not just limited to three years, so that the range of research can be broader and the results of research become more accurate. (3) Researchers are able to add other independent variables that influence company values, such as liquidity, leverage, dividend policy, exchange rates, interest rates, inflation, and others. (4) Further researchers should not only use annual reports to obtain data related to ERM Disclosure and CSR disclosure conducted by companies, but can also expand coverage by looking at reports that are on company websites, print and electronic media.

\section{REFERENCES:}

Agoes, Sukrisno., dan I Cenik Ardana. 2009. Etika Bisnis dan Profesi. Edisi Revisi. Penerbit: Salemba Empat.

Ardimas, Wahyu., dan Wardoyo. 2014. Pengaruh Kinerja Keuangan dan Corporate Social Responsibility Terhadap Nilai Perusahaan Pada Bank Go Public Yang Terdaftar di BEl. Seminar Nasional dan Call for Paper. ISBN: 978-602-70429-1-9, 231-238.

Agustina, Linda., and Niswah Baroroh. 2016. The Relationship Between Enterprise Risk Management (ERM) and Firm Value Mediated Through The Financial Performance. Journal of Integrative Business \& Economics. $5(1)$.

Brealey, Myers, dan Marcus. 2011. Dasar-dasar Manajemen Keuangan Perusahaan. Cetakan ke-5: Erlangga.

Committee of the Sponsoring Organizations of The Tradeway Commission. 2007. Enterprise Risk Management, Integrated Framework (COSO-ERM Report). New York: AICPA.

Devi, Sunitha., I Dewa Nyoman Badera., dan I Gusti Nyoman Budiasih. 2016. Pengaruh Enterprise Risk Management Disclosure dan Intellectual Capital Disclosure Pada Nilai Perusahaan. Simposium Nasional Akuntansi XIX. Lampung.

Fitri, Riana Anugrah., Eliada Herwiyanti. 2014. Pengaruh Corporate Social Responsibility dan Good Corporate Governance Terhadap Nilai Perusahaan. Jurnal Ekonomi.

Handriyani, Arik Novia., and Andayani. 2013. Pengaruh CSR Terhadap Nilai Perusahaan Dengan Profitabilitas Sebagai Variabel Moderating. Jurnal IImu \& Riset Akuntansi, 2(5).

Hariyanto, Marina Suzuki dan Putu Vivi Lestari. 2015. Pengaruh Struktur Kepemilikan, IOS, dan ROE Terhadap Nilai Perusahaan Pada Perusahaan Food and Beverage. E-Jurnal Manajemen Unud. 4(4).

Husaini, Achmad. 2012. Pengaruh Variabel Return On Assets, Return On Equity, Net Profit Margin Dan Earning Per Share Terhadap Harga Saham Perusahaan. Jurnal Profit. 6(1).

Kartini, Dwi. 2009. Corporate Social Responsibility, Transformasi Konsep Sustainibility Management dan Implementasi di Indonesia.

Kieso, D.E., Weygandt, J.J., and Warfield, T.D 2014. Intermediate Accounting IFRS Edition. United States Of America: Wiley.

Languju Octavia., Marjam Mangantar., dan Hizkia H.D.Tasik. 2016. Pengaruh Return on Equity, Ukuran Perusahaan, Price Earning Ratio, dan Struktur Modal Terhadap Nilai Perusahaan Property and Real Estate Yang Terdaftar di Bursa Efek Indonesia. Jurnal Berkala IImiah Efisiensi. 16(02).

Putri, Cintamy Prananti. 2015. Analisis Pengaruh Rasio Profitabilitas Terhadap Nilai Perusahaan Manufaktur Sub-Sektor Otomotif dan Komponen Di Bursa Efek Indonesia. Jurnal Ekonomi.

Retno, Reny Dyah., and Denies Priantinah. 2012. Pengaruh Good Corporate Governance dan Pengungkapan Corporate Social Responsibility Terhadap Nilai Perusahaan. Jurnal Nominal, 1(1).

Triagustina, Lanti., Edi Sukarmanto., dan Helliana. 2014. Pengaruh Return on Asset (ROA) Dan Return On Equity (ROE) Terhadap Nilai Perusahaan Pada Perusahaan Manufaktur Subsektor Makanan Dan Minuman Yang Terdaftar Di Bursa Efek Indonesia 2010-2012. Jurnal Akuntansi. 
Sanjaya, Chyntia Kartika., and Nanik Linawati. 2015. Pengaruh Penerapan Enterprise Risk Management dan Variabel Kontrol Terhadap Nilai Perusahaan di Sektor Keuangan. Jurnal FINESTA, 3(1), 52-57.

Wulandari, Ika Ayu., Zaky Machmuddah., dan St. Dwiarso Utomo. 2016. Manajemen Laba, CSR Disclosure dan Kinerja Keuangan. Simposium Nasional Akuntansi XIX. Lampung. 